\title{
Stratigraphies: archaeology as a threshold and passage
}

Antonello Marotta

Like every phase of the history of thought, the contemporary age ponders over the meaning of the past. Thinking back over places that already have a history in the archaeological sense leads us to certain questions that concern, at close range, our way of understanding design, the city and the territory. The need for the ideas of our times to interact with these sites, with their sedimented past, has determined a variety of solutions, some with a historicalphilological focus, others aimed at revitalisation, yet others in which design chooses the path of non-intervention and, finally, some - and this is the aspect we will analyse - aimed at interacting and creating contact with the past, with a mechanism fit to generate new spatial, social and behavioural principles.

This vision necessarily considers the past as matter that is alive and under tension, and grasps bonds with it as extraordinary opportunities, excludes mimicry and philology, aware that the past as such has changed over time. What remains is a substance endowed with meaning, a meaning that comes alive again through interpretation and the yielding of value and new life to the present.

The design discipline is implementing numerous courses and we can summarise them under the concept of archaeology and trace. ${ }^{\mathrm{a}}$

Archaeology is a subject linked by its nature to history and calls up an archaic dimension, whereas the trace takes us into the world of interpretation, analysis, and research based on circumstantial evidence.

In Post-modern years there was talk of the end of narration and of the need to focus once more on the list. According to this idea the necessary information had to be retrieved from the past and could then be freely assembled to form a framework, but it gave debatable results for architecture was being turned into an eclectic, citationist construct.

\footnotetext{
Correspondence: anto.marotta@tiscali.it

University of Sassari, Architecture at Alghero (AAA), Department of Architecture Planning and Design (DADU), Palazzo del Pou Salit, Piazza Duomo 6, 07041 Alghero, Italy
}

We need to take a step backwards, towards the end of the Sixties, to pick out, from among the themes investigated by Michel Foucault, reflections on history that in present times refocus on disciplinary aspects.

In 1969, with L'archéologie du savoir (The archaeology of knowledge), the French philosopher had undermined the model of history that advanced, recorded and invoked strata, archaeological levels and thresholds founded on different planes, involving the city as much as society. Foucault maintained that the strata of history overlapped, "they intersect without being able to be reduced to a linear pattern" (Foucault 1980). The French philosopher had formalised this unavoidable relation between memory and past, including life as an internal process. History, eliminating the irruption of events, was interpreted as an ideal, coherent and, consequently, linear model. Foucault introduced the principle of heterotopia, of the co-presence of various times in the same place, belonging as much to the past as to the present. Memory is deeply different from the past, in that it is coloured by the present, is alive and "darns" experiences, rewriting them to be able to exist and be able to carry on narrating. Whereas the past, as such, shows what there was, the times passed through, what has inexorably disappeared. Memory, on the other hand, questions time, calls it back to itself like a pressing need of redefinition. With L'archéologie du savoir, Michel Foucault challenged a structure of knowledge that was unidirectional, linked with univocal power, calling up differences, schedules and the multitudes of signifiers and polysemic elements.

The analysis the French philosopher constructed on history adapts well to highlighting the stratigraphic and topographic complexity of the city, analysed in its evolution. The city sums up different times and phases of development in its structuring, so as to make it a complex structure of passages, and of temporal thresholds.

Nowadays we are witnessing a series of poetics that put the processes of history back into motion, with their themes of ruins, archaeology and traces.

\section{Springer}

(c) 2014 Marotta; licensee Springer. This is an Open Access article distributed under the terms of the Creative Commons Attribution License (http://creativecommons.org/licenses/by/4.0), which permits unrestricted use, distribution, and reproduction in any medium, provided the original work is properly credited. 
As the specific conditions of places change, we encounter a different approach to the way the archaeological project is understood. Undoubtedly, in this we need to record the idea that the context has become a more complex system compared with the theorising that pervaded the Seventies.

We are aware, in the reflection concerning the relation between archaeology and project construction, that the relationship that becomes established over time is nurtured by an interpretative dimension, and that architecture cannot be activated as a pre-determined, selfreferential model so much as in relation to the specificity and differentiation of contexts ${ }^{\mathrm{b}}$.

Type analysis is no longer understood as a pure, unchangeable model, but as one substantially altered by evolution and the transformation of time, with life reappropriating spaces once born with different aims. It was Rafael Moneo who reread the relationship between typology and city.

As for Aldo Rossi's ideas, Moneo analysed architecture through the concept of time, "understanding that the Rossi type is, following the more mature formula of 'Scientific autobiography' (1990)", a form that has "struggled with time to the point of being destroyed by it" and to the point of being, simultaneously, confirmed in its essence; a form that has undergone, and accepted, changes, events, accidents opposing it, and that being subjected to stress and distortion, freed itself from the principle of author" .

Hence, in the Nineties typology became too rigid a system to analyse and give an answer to the context. To broaden the idea of context means to oppose the contextualism that reigned in Post-modern years, in which analogy and mimicry often constructed projects that gathered information of a historic or material type from the site, laid out in registers and volumetrically. The site is understood these days as a set of layers that interact: historic, social, constructive, material and also conceptual and mental. Design reacts to the place by leaps between one system and another, until it intersects the question with a single solution.

A series of guidelines arise from this: those that refocus on the concept of time, archaeology, modernity as a potential project, and material and spatial rules. This research should be understood as a continuation of the modern lesson ${ }^{\mathrm{d}}$, made topical in the present time and laid down on the social and political reality of a specific context.

The urban and environmental territory ask the designer to improve on the consolidated spatial models, given that design is born from the interaction of many responses, both physical and material, but certainly cultural and linked with contingent evolutional aspects.

Studying archaeological literature and interventions born with the aim of conserving and innovating ancient matter, one detects that they contain interpretative routes suitable for understanding the changes in design and contemporary theory.

Whereas functionalist theory had analysed the site basically as a white sheet on which to graft design autonomously with respect to the evolution of the city, and in the Post-modern period design had to converse with the urban mesh as an unexpected sign and one of continuity, it is now the archaeological places that are the ones where the intervention has to "darn" different histories, heterogeneous fabrics endowed with time, contexts marked by the complexity of the city and environmental territories.

Rafael Moneo recently offered us one of the most interesting interventions on the relation between archaeology and architecture, in a system that analyses thresholds and temporal passages.

At Cartagena in Spain the discovery of the Roman Theatre (1st Century BC) in the area of the church of Santa María la Vieja, an excavation campaign was begun in 1988 that brought to light a Roman theatre of extraordinary quality. The site had deteriorated physically and socially, leading the authorities to publicise an overall project to uncover the archaeological site and renovate the entire urban system.

Moneo theorised on the need for contemporary design to exclude the pursuit of form, with the idea that architecture, first and foremost, is a constructive and social project. His reflection brings back architecture as city design, beyond the author's personalism, and in search of deep ties. The plastic study model is illuminating from this point of view, in that the site has extraordinary riches that can be linked up by connecting the various levels of the city. Specifically, the themes here are various: the recovery of a structure with an eclectic facade, built at the end of the 18th Century, the presence of an 8th -9th Century curtain wall with an unbuilt area and on an axis, at the higher level of the city, the cathedral, which lies in a state of semi-ruin. Once the excavation work on the theatre had been finished, the church rested solidly on a ring of the ancient Roman structure, recalling the construction processes of the ancient city, in which rights and functions were perpetuated and where sacred architecture was born adhering to pagan manufacture.

The Master from Madrid worked on mediation between the different historic and topographic levels of Cartagena and created a museum system based on the theme of the passage and thresholds between the different times of the historic, modern and archaeological city. He therefore situated the entrance in the Palazzo di Pasqual de Riquelme, creating a route beneath streetlevel to link up with the museum, which he constructed in the urban void of the built facade. He created it as a compact building, enlivening the facade with gentle sliding 
so that light could enter. It is a project that can be perfectly understood in its general profile. In the restored Palace functions have been added: display rooms and a small auditorium on the ground floor, offices and rooms for exhibitions on the first floor and classrooms and a library for the Roman Studies Centre on the top floor. The different height between the Palace and the new museum was coped with by an underpass with exhibition space that leads into the new building, characterised by rooms with double height, in which vertical dizziness prevails, and where light penetrates through skylights studied for the purpose. A system of escalators enables one to go back up and finally leads into the cathedral, with a ramp that retrieves historic traces. The visitor ultimately reaches the rediscovered place, protected and enclosed: the Roman Theatre. At Cartagena Moneo questions the site and models it, convinced that it is the city in its evolution that represents true archaeological matter. Everything concurs to outline a project that has the theme of the passage and thresholds as its reason for being. In this way history collaborates and the different phases of the urban settlement are joined up. The cathedral, with its collapsed roof, has been left as a memento of itself. The archaeological area has been enclosed by a wall that delimits it and gives it back, by this closure, to the whole community.

The idea of stratification, of the different times and thresholds, that Foucault had singled out as a process of history, was applied in this intervention ${ }^{\mathrm{e}}$. Moneo seeks continuity and differences, in a univocal choice of material that makes everything coherent, as in Spanish tradition, while it is the spaces that varies depending on the surrounding conditions and records its specificity, its being tied to the place, precisely through the differences.

\section{The archaeology of light: grafts and sections}

Moneo teaches us that interventions in archaeological areas place the focus back on a complex idea of city, of physical and social, constructive and material relations. The main theme becomes light as a rebirth, to bring a monument-document back to life that was hidden under a mantle of earth.

Light and gravity, and the weight of the architecture as a process of excavation and investigation have become essential elements of a new way of analysing archaeological remains. Moneo's museum cannot, therefore, have a direct relationship with light, but everything is experienced internally like indirect action, with mechanisms suitable to make light penetrate and steer it into dilated spaces, which remind us that the museum, as such, is not only a place to conserve and display finds, but also a complex space in which architecture communicates an involving, emotional experience aimed at discovery.

Everything has its origin in the past, when the Romans created great structures: we are thinking of the Pantheon, in which an oculus projected light inwards. With its gradations it calibrated the body weights of the great masses that slid from the dome down to the precious marble floors. Light creates continuous variations in the different periods of the year, but above all generates an intimate space in which man perceives a sense of greatness linked with the substantial dilation of the space.

This was a lesson on light, the mass and the weight of architecture that was the engine for many architects who espoused this relation with light and gravity in a different way. Suffice it to think of the work of Louis Kahn, who discovered on his second journey to Italy the weight of the mighty walls and, above all, the light that gave sense to space, made it vibrant and alive. When we look at his production we discover a change in route from the projects of the Fifties, when he was in contact with Richard Buckminster Fuller's research and produced experiments on reticular structures, to those following his journey to Rome, where he lived at the American Academy between 1950 and 1951. The architect of Estonian origin understood that geometry is a vehicle to incorporate time, that it is not enough as a matrix of space, and that it needs a thick wall to make architecture still a mystery that speaks to man and his institutions.

In the period spent in Rome he visited Villa Adriana, the Terme di Caracalla and the Pantheon, and was fascinated by the mysterious light of its ruins ${ }^{\mathrm{f}}$.

This theme became an important engine in reviewing the present, in that ruins enable us to transcribe and rewrite the spatial experiences on which architectural thought is founded. We know that Kahn achieved this contact with history not just by spontaneous reading and his splendid coloured drawings full of emotions, but also, and above all, through visionary literature. I am referring to his intellectual relation with the work of Giovanni Battista Piranesi ${ }^{g}$, who became a reference point for his anti-perspective gaze on the world. In his works like Invenzioni Capric [ciose] di Carceri [Capricious Inventions of Prisons], developed between 1745 and 1750 and revisited in the 1761 edition (Carceri di invenzione [Imaginary Prisons]), there is no longer the stability of the objective space of Renaissance perspective, but one that dilates and accelerates outwards, beyond the confines of the picture and the frame itself: dynamic, interwoven space ${ }^{\mathrm{h}}$. Piranesi had understood that the past and ruins could still speak to the present, in the sense that time - atmospheric, existential and mental - had regained possession of its matter. It was a context in which rationality and instinct coexisted; the ideas of Apollo and Dionysus together. Time, combined with space, became the deus ex machina of this architecture. 
What did Louis Kahn retrieve from this lesson?

On the occasion of the Salk Institute project, Kahn developed drawings based on the 1762 Plan drawn up by Piranesi for the Campo Marzio, inspired by the plan of ancient Rome. Kahn was able to reread Piranesi's incisions, those of Villa Adriana, which he had developed in different phases of his life up until he died in 1778. From these the American architect grasped the meaning of time, memory and of transformation. The partially collapsed vaults offered, in these gaps, the vital space for rewriting memories ${ }^{i}$. Here nature was not a place already given, but an interpretative matrix of what man's destiny could be in relation to time. Kahn was attractive because of his scarred face, his mysterious humanity and the complicated life he had lived. History for him was never a linear journey but always diagonal, like an arrow that encounters different moments of history and condenses them. We understand this indirect dimension with the past, and this need to pass through the metaphor, to the point of including the visionary world of John Soane in his interests.

An architect and collector, he was a complex figure who worked as a superintendent of the Bank of England from 1788 to 1833 . When he thought of his work, he developed it from the inside, modelling it like a dream of a golden past. In an incision by Joseph Gandi (1830) the Bank translates into a great excavation: a ruin, of which time has taken back the walled structures to the point of revealing its archaeological soul, its intimate disposition. Kahn grasps the sense of time and of structures that, losing their trimmings, titanically remain on their feet, like a foundation.

John Soane left us another archaeological document of his house, now a museum, situated in Lincoln's Inn Fields in London, where he lived from 1813 till 1837, the year of his death. In the rooms full of exhibits the past lives again one next to the other to generate memory as an infinite stratigraphy. But above all he excavated his house in profile, with mobile panels able to show the space beyond the stage.

This dimension of the excavation, the section, the internal light raining from above, is an integral part of the world of Louis Kahn. In light the architect seeks the dimension of time and man together, like an act of hope. Light and silence were to be the two kinds of matter that he would seek indefatigably for the rest of his life. In this interval, as if between two vital fires, architecture takes place, as he recalled in 1968 during a conference held at the Guggenheim Museum in New York: "I consider light the source of every presence and matter is worn-out light. What light creates, projects a shade and the shadow belongs to light. I perceive the presence of a threshold, which separates light from silence, and leads silence to light, immersed in an inspired atmosphere, where the desire to be and to express encounters the possible" .
Light, the section and the visionary world of John Soane come down to our times, to demonstrate that design culture seeks something deeper than facile citation, or the paradox of the analogous. It was Juan Navarro Baldeweg who led us inside this tension between modernity that never ended and a vast time, rich in history but never nostalgic, purified of mimicry and in search of new definitions, like patterns that clean up trimmings in a Kahnian manner. In Rome he created the Biblioteca Hertziana in 2012. The eternal city is the place of memory par excellence and the building belongs to the Palazzo Zuccari, once the home of the artist Federico Zuccari, who had built it in 1590 on a wedge-shaped piece of land in the area of Trinità dei Monti ${ }^{k}$. The dwelling was built on the remains of the Roman villa and the gardens of Lucullo, arranged in terraces, following the orography of the site. Navarro Baldeweg speaks of an identity between permanence and transformation. For the Biblioteca Hertziana project the Spanish Master recuperated the terrace arrangement of Villa di Lucullo. It was an intervention that revealed itself in the profile; in a sketch his work is understood, that of creating internal space through light. A large basin of light pushes the internal masses, like terraces in a dialogue with the scenographic void obtained. It is a work carried out following a diagram that retrieves from history the sense of the place, translated into a large space of light. Navarro Baldeweg works to make the space the narrative matter, while the various levels are laid out to accommodate the reading-tables and bookshelves. To work on a historic palace of such great importance means, in the first instance, to understand the building, its internal rationality and constructive logics, but above all to prompt a new identity. The section thus becomes, together with light, the instrument that enables excavation, and modelling of the interior like archeological action ${ }^{\text {. }}$

Navarro Baldeweg, like Louis Kahn before him, teaches us to look at history with a careful gaze, always ready to redefine the confines of disciplinary practice, making the wealth of the past converse as much as the abstract force of modern ideas.

\section{The territory as an archaeological trace}

Over the last few years new support has developed in design theory for themes of the territory and the environment, in which the context's relations affect the work of design. Namely, research inquiring into the urban dimension and the territorial one and into the relationships that exist today between the two systems. In recent years the analysis of the city has indeed changed, since the axis shifted from the historic nucleus to the outskirts, as far as the external territories, and since the city exploded, losing definition in systems characterised by 
the absence of rules, and setting off the social and economic problems this involved.

The increasingly complex territories of our times lead us to analyse edge areas, that have been excluded or are at the margins, like abandoned quarries and sites rich in memory, which conserve an archaeological identity in themselves, understood as a deep, archaic dimension. This is the great challenge of the near future: to consider the city in a wider sense, that incorporates the territory as a founding part. Placing the accent on the environment, and on considering nature as an ally and not a resource to exploit, is today putting design practices back in the centre.

The crisis of traditional methods of planning the territory is a consequence of the incapacity to consider the environment as an integral part of the urban system.

In the tracks of Fernando Clemente, research was born in the low-density territories of Sardinia which focused on the environmental issue. The natural, anthropic environment was analysed as potential for development, when the rational model of exploitation of the territory had put all its own limits in place Maciocco 1991.

Giovanni Maciocco has organised the work over the years considering environmental design as city construction. In his theoretic and design-oriented reflection the architect coined the term urban potential of the territory, pinpointing a wider conception of city with this expression, to incorporate the countryside, villages and external territories, and cast off the separation between "the compact city and other urban morphologies" Maciocco et al. 2011.

It is a monumental transition, explains Maciocco, between an autocentric spatial model of the modern city and "the territory, [which] as a place in which city and nature encounter each other, is the space available to design for possible reorientation of the city around places rich in nature and history" .

The territory is, for the architect, cartography that observes data, information, traces, market gardens and historic gardens, infrastructure, archaeological sites and industrial settlements, contour lines, environmental dominants, and geological and hydrogeological stratifications. The whole set of factors of natural and anthropic evolution forms a complex framework, each context of which brings with it traces of the history, crises and potential it is endowed with. It is the task of design to select and reveal the traces. In his work the territory is the map of the project; he believes that each intervention will not address proximity values, but be the expression of environmental dynamics, those that enable the city to establish new spatial and social values. The aim is to consider the great territorial signs as matrices of contemporary intervention.

Due to its centuries-old geological and archaeological history, the territory leads us to consider the dimension of time as founding its identity. This temporal dimension lives in the differences, marginal wealth, copresence of nature and artifice, altimetric and geological variations and in the mythology of places, which conjure up the most archaic matrixes ${ }^{\text {n }}$.

The territory is the result of stratifications, so a methodology needs to be built up that will enable us to glance through a place and analyse it, with the aim of generating new spatial processes on the traces of nature and history. A combination is identified between the world of the real and the infinite conditions of the possible: design analyses the mutations and seeks an alignment between the potential introduced and the reality on which intervention will take place.

Consequently, compositive theory pays attention both to the constructive aspect and to that of process, which works on the relations between nature and artifice. Time becomes the principal actor in design for the territory, also as a capacity for long-term forecasting, to activate possible development scenarios. The city is considered a whole territory, but to do this we need to put aside a conventional urban idea. When we intervene in environmental areas, in which the forces of nature predominate, design cannot call up the compact, massive image of the city so much as work on the traces of the territory, where nature has been moulded by man in long-term temporal processes. To analyse these territories is the purpose of research on design, in areas where the environmental values dominate over the rest and can, and may, be the real attractors of development. Relations have substituted the aspects of proximity, the synaesthetic component the purely objective one.

If we enter into the action of Giovanni Maciocco's designing we understand how his work is a dialogue between territory and archaeology. Let us analyse two works: The National Museum of Olbia and the Anglona Paleobotanical Park ${ }^{\circ}$.

Archaeology is the subject able to trigger new questions in present times, addressing the memory, conservation of the territory, and the defence of the deepest strata of a culture. In Olbia, Giovanni Maciocco completed the Archaeological Museum in the harbour area in 2007. The wrecks of Roman and Mediaeval ships, discovered during the excavations of the ancient harbour, urged the authorities to create a museum able to document the archaeological history of the Mediterranean, with the routes and pathways that in past times represented the History of Sardinia. Each journey, ancient and contemporary, represented an opportunity for a project. The architect was aware of this. The project was born in 1987 and it took twenty years to complete. This is typical of the difficulty in Italy of creating a public work as complex as that of a museum of the territory. 
The time delay decreed the fortune of this project, which was born already mature, with plenty of time for reflection. The designer's reference base addressed principles taken from past architecture and grafted onto modern tradition. The islet named Peddona became the base on which the building was constructed. The museum defines a void, delimits and demarcates it. An early Twentieth century block is embedded within the museum courtyard. Its rotated position creates spatial tension in the internal enclosure, reminding us of the role of pre-existing elements. The museum grew over the years, was not an operation characterised by additions, but as partitions were erected they dictated the space. The construction site was the place where the composition revealed itself. Before the building was completed, the structures perfectly narrated the myth and archaeology aspects: they are slabs that delimit, diaphragms that create transit and relational spaces, walls that separate. Thus, the project grew and took shape around two areas of tension: two gaps that shape the space, one obvious in the large rectangular courtyard onto which the internal space expands, and an internal one with a circular ring, a drum dictating the internal movement and creating a dynamic area around which the whole composition revolves.

The museum is a compact building but constantly evades definition, in its slabs and bodies that build up a sliding of the masses, generating interstitial spaces of great interest. One photo is emblematic: it shows a ship moored at the quay and the profile of the museum in perspective. They are two potential masses: one ready to move off, following its nature and function, while the other exists on being part of the territory, in narrating its rooting to the place. The journey of the ships, of which the museum conserves the remains, is not only a metaphor of contemporary design, but identifies the capacity of a designer to interpret history and to take steps to select the materials and skills able to construct his personal vision. The solution for the external treatment of the Archaeological Museum is a material that gives form to the structure and calls up the architecture excavated from stone. Observing the profiles of the facades we grasp this desire to articulate the mass, as in the processes of excavation of the Roman works, with bodies sometimes heavy and sometimes as narrow as blades, to accommodate the various functions: exhibition halls, conference rooms, offices and public spaces. Access to the museum is by a walkway that leads to the area of the exedra. Here we discover a very interesting intermediate space, obtained thanks to the transfer of a curved wall that contains a steel ramp leading to the walkway and belvedere mechanism to discover the territory.

If the museum was meant in the Eighteen hundreds as a complex showcase that listed the heritage of past history in its spaces, today the memory expands outwards, into the environmental context, in the link that unites the city of Olbia with Isola Bianca, to the point of incorporating the coastline. This awareness of the weight of the territory in city construction is a constant in Giovanni Maciocco's theoretic and spatial research. Thus the museum exists on an internal space that guards memory, in the archaeological finds of the ships discovered, and a panoramic one that reminds us that it is the territory that is the heritage the present needs to be able to protect, in that the challenge of the near future consists indeed of the capacity to create international policies for development.

Hence, the Archaeological Museum is a stable machine, rooted in the harbour of Olbia: on the one hand it defends memory, in the discovery of the Roman ships, while on the other it considers the territory the true narrative motive.

The opportunity to invest in the relation between environment and archaeology was put into practice by Giovanni Maciocco with the Paleobotanic Park of Anglona, created in a silent, vital context, that of Sardinia. The designer materialised the construction of the territory on environmental principles. The discovery of a petrified forest in an area of approximately $100 \mathrm{sq} \mathrm{km}$ in northern-central Sardinia, which includes the municipalities of Martis, Bulzi, Laerru and Perfugas, encouraged the authorities to develop a park to bear witness to the memory of the place. The design of a park, linking up a vast territory like that of Anglona, led the architect to develop the construction of territorial machines, shaded galleries, with the purpose of creating visual and physical communication between the natural elements, geological sedimentation and the presence, in contact with the urban nuclei, of religious monuments. The artistic literature of past avant-gardes returns, of the revolution in territorial art in Paul Klee's works, like Highways and Byways (1929). In a crucial phase in the history of mankind, straddling the years of the First World War, artists began to consider the territory no longer in analogical form so much as diagrammatic, following models and principles in which space is dictated by roads that intersect and by an inextricable relation between point, line and surface, in which the presence of timely architecture exists on the relations between physical trajectories and natural matrixes. Giovanni Maciocco works on the territory like a cartographer, able to read and re-read in the signs shaping it the lines of development of a project. This is not laid down, as in an abstract operation, but comes alive as a consequence of the need for development that the territory asks be recognised and implemented. The theoretical and project-based reflection is founded on the awareness that the city is no longer or just the compact one of the old centre or the widespread 
one of the outskirts, but has extended over the external territories that become, through the rediscovery of environmental dominants, poles of attraction and new centres of development. Thus the Paleobotanic Park of Anglona develops the principles of city construction, a city understood in the environmental way. The designer works with load-bearing structures in wood, built with $8 \times$ $8 \mathrm{~cm}$ rods, shaped by a secondary framework of strips placed horizontally. These hollow bodies define a wrapper that moulds the internal space.

The layout of the load-bearing structure with windbracing makes these bodies resistant, not just statically but in their relation with the landscape. The petrified forest does not appear as a forest of stone: it is more a question of fossil concretions located within the park. How, then, should one work with these remains and with the need also to reconstruct contemporary narration?

Territorial art has made one principle emerge: it is the horizontal that wins over the vertical; it is the slow advancement and differentiation of the landscape that defines the visual and physical horizon of the project. If the creation of the shaded galleries follows a construction rule, in the rods that define a gap, here a principle wins that is not only tectonic. The Martis, Bulzi, Laerru and Perfugas galleries, though based on an axiom that unites them as a category, show four distinctive characters. Giovanni Maciocco works on the territory, but selects the settlement conditions from it that are able to characterise spatial identity and significance. The four shaded galleries are generated and moulded from the territory: that of Martis lies in a valley, in Bulzi it follows the crest of a hill, the Laerru one winds along and peters out along the promontory and, finally, that of Perfugas is strategically placed to dominate the valley. The shaded galleries are defined by panels that being at split-level enable the landscape to enter inside. The rods generate a play of light and shadow when the sun passes through the woven wood. But undoubtedly, from afar these territorial machines have the charm of symbolic spaces: we grasp not only their functioning, but also a form that captures the territory. They are moulded masses, prisms modelled from the land, from the nature of the places. To genius loci interpretations (the divinity of places that characterises a site) and those of sedimentation (the awareness that the context is the sum of the actions Man and Nature have established over thousands of years), the Paleobotanic Park of Anglona introduces the principle of ecology, namely, the recognition that identity and stratification, mentioned above, are interconnected, that every ritual is born from a previous one, and that all archaeology incorporates more ancient archaeology. The structures, in this suggested void, hold the territory's breath.

\section{Endnotes}

a The themes connecting architecture with archaeology have been dealt with by the writer in his Ph.D. research: Antonello Marotta, Il progetto di architettura e le aree archeologiche. Il parco archeologico di Atella, XVII ciclo. To further understand the modern design/archaeology relationship with regard to the past and the journey of the masters of modernity, refer to the text: Alberto Ustárroz, La lección de las Ruinas. Presencia del pensamiento griego y del pensamiento romano en la arquitectura, Arquíthesis 1, Fundación Caja de Arquitectos, Barcelona 1997.

b For further reading: Antonello Marotta, Mansilla + Tuñón, Edilstampa, Rome 2012

${ }^{\mathrm{c}}$ In his text La solitudine degli edifici Moneo seeks the long period of history and resistant matter, in which the work lives, in its solitude, autonomously from the architect who conceived it, while in Inquietudine teorica he goes further into the aspects of design, gathering processes and methods, rational and hazardous attitudes of central figures of the debate of the Eighties and Nineties. The reflection of the Master from Madrid indicates that design does not only address physical space, but more deeply social, political, material and constructive space. Several sites that interact in the same place. To study further the thoughts on Moneo, refer to the following texts: (Leoni 2003; Quetglas 1997; Moneo 1999; Moneo 2005a,b; Moneo 2007).

${ }^{d}$ For further reading on the themes of memory in the Twentieth Century: Rella 2003

e As regards the relation between museum and archaeology: Marotta 2010. On the evolution of the museum: Costanzo 2007; Marotta 2013b.

${ }^{f}$ See one of the more thorough texts: MacDonald and Pinto 1997

g For an accurate reconstruction, both historic and iconographical, see: Ficacci 2000. For further reading about the consideration of Piranesi see the essays: Purini 2008; Tafuri 1980; Wilton-Ely 2008.

h Manfredo Tafuri wrote in 1973: "But the Carceri [Prisons], precisely because they are endless, coincide with the space of human existence. The hermetic scenes drawn by Piranesi, in the links of his "impossible" compositions, point to it with extreme clarity. Which means that in the Carceri we can only see the new existential condition of collectivity, freed and condemned at the same time by its own reasoning. And it is not so much a reactionary criticism of the social promises of Illuminism, which Piranesi translated into images, as a lucid forecast of what a society should be when freed from ancient values and the consequent constrictions imposed by them. The experience of anguish makes, in Piranesi, its first appearance in a modern form. In the Carceri we are already in the presence of anguish generated by the 
anonymity of the subject and the "silence of things". Taken from Tafuri 2007.

${ }^{\mathrm{i}}$ During a conference held in 1965 at Fort Wayne Fine Arts Center the architect said: "Piranesi drew Rome in a way that had never been done before. He drew visionary figures and great spaces where art could be put on show. He imagined things, like Jules Verne. He imagined things that later proved to be real. The way he represented the entry into vast spaces has always been a source of inspiration for architects. That is how I imagined them". Taken from Bonaiti 2002. While Tafuri reads the end of an organic city model in the action of collages of the types implemented by Piranesi in the Iconographia Campi Martii of 1762, Kahn, isolating a fragment of the imaginary plan, makes this portion of utopia live again in one of the most important works of the Twentieth Century, the Salk Institute for Biological Studies.

j Louis Kahn's text, Architettura silenzio e luce, written on the occasion of the conference held at the Guggenheim Museum in New York on 3 December 1968 is taken from Maria Bonaiti, Architettura è. Louis I. Kahn, gli scritti, op. cit., p. 134. Later Kahn was to give a lesson on the same themes at the ETH School of Architecture in Zurich. To read the text Conferenza all'ETH, refer to Norberg-Schulz 1980.

${ }^{k}$ To understand the Biblioteca Hertziana, see: Müller 1992. As regards the theme of reconversion and reuse: Pinon 1999.

${ }^{1}$ On the composition, section and relationship between concept and space: Navarro Baldeweg 1992, 1996.

${ }^{\mathrm{m}}$ Ibid., p. 11

${ }^{\mathrm{n}}$ On these themes see the critical essay: Maciocco 1995.

- On the trace-territory relationship: Giovanni Maciocco. Architecture, Environment and Beyond, edited by Huber and Lupano 2007.

\section{Competing interests}

I declare that I have no competing interests.

Received: 2 October 2013 Accepted: 31 March 2014

Published: 6 August 2014

\section{References}

Bonaiti M (2002) Architettura è. Louis I Kahn, gli scritti. Electa, Milan

Costanzo M (2007) Museo fuori dal museo. Nuovi luoghi e nuovi spazi per l'arte contemporanea, Franco Angeli, Milan

Ficacci L (2000) Giovanni Battista Piranesi. Taschen, Rome

Foucault M (1980) L'archeologia del sapere. Una metodologia per la storia della cultura. BUR, Milan

Huber A, Lupano M (eds) (2007) Giovanni Maciocco. Architecture, Environment and Beyond, Skira, Milan

Leoni G (2003) Rafael Moneo: architettura come architettura. Area, 67-11

MacDonald WL, Pinto JA (1997) Villa Adriana. La costruzione e il mito da Adriano a Louis I Kahn. Electa, Milan

Maciocco G (ed) (1991) Le dimensioni ambientali della pianificazione urbana. Franco Angeli, Milan

Maciocco G (1995) Ritorno a Ithaca/Return to Ithaca. In: Huber A (ed) Territorio, sito, architettura/Land, site, architecture. Lybra, Milan, pp 195-247

Maciocco G, Sanna G, Serreli S (eds) (2011) The Urban Potential of External Territories. Franco Angeli, Milan
Marotta A (2010) Atlante dei musei contemporanei. Skira, Milan

Marotta A (2013a) Tracce/Traces. Industria delle Costruzioni 429:4-101

Marotta A (2013b) Typology quarterly: museums. Archit Rev 1391:75-85

Marotta A, Archeologie/Archaelogies (2010b) Industria delle Costruzioni, n. 414: 4-99 Marotta A (2012) Mansilla + Tuñón. Edilstampa, Rome

Moneo R (1999) La solitudine degli edifici. Casabella 666:30-31, 33

Moneo R (2005a) Sul concetto di arbitrarietà in architettura. Casabella 735:22-33

Moneo R (2005b) Inquietudine teorica e strategia progettuale nell'opera di otto architetti contemporanei. Electa, Milan

Moneo R (2007) Costruire nel costruito. Allemandi, Turin

Müller B (1992) Palazzo Zuccari a Roma. In: Hüttinger E (ed) Case d'artista. Dal Rinascimento a oggi. Bollati Boringhieri, Turin, pp 102-112

Navarro Baldeweg J (1992) La geometria complementare. Lotus 73:110-112

Navarro Baldeweg J (1996) Movimento davanti all'occhio, movimento dell'occhio. In: Gonzáles García A, Lahuerta J, Juan Navarro Baldeweg J (eds) Opere e progetti. Electa, Milan, pp 63-68

Norberg-Schulz C (1980) Louis I Kahn, idea e imagine. Officina Edizioni, Rome

Pinon P (1999) Le riutilizzazioni architettoniche nella storia. Area 45:4-7

Purini F (2008) Attualità di Giovanni Battista Piranesi. Melfi, Libria

Quetglas J (1997) La danza y la procesión: sobre la forma del tiempo en la arquitectura de Rafael Moneo. El Croquis Rafael Moneo 1990-1994 64:26-45

Rella F (2003) Miti e figure del moderno, Letteratura, arte e filosofia. Feltrinelli, Milan

Tafuri M (1980) La sfera e il labirinto: avanguardie e architettura da Piranesi agli anni '70. Einaudi, Turin

Tafuri M (2007) Progetto e utopia. Editori Laterza, Rome-Bari

Wilton-Ely J (2008) Giovanni Battista Piranesi 1720-1778. Electa, Milan

doi:10.1186/2195-2701-1-9

Cite this article as: Marotta: Stratigraphies: archaeology as a threshold and passage. City, Territory and Architecture 2014 1:9.

\section{Submit your manuscript to a SpringerOpen ${ }^{\circ}$ journal and benefit from:}

- Convenient online submission

- Rigorous peer review

- Immediate publication on acceptance

- Open access: articles freely available online

- High visibility within the field

- Retaining the copyright to your article

Submit your next manuscript at $\gg$ springeropen.com 